\title{
Marine Ecology of La Reunion: An Overview of Recent Research
}

Reunion Island (Fig. 1), which is part of the Mascarene archipelago, is located between $21^{\circ} 07 \mathrm{~S}$ and $55^{\circ} 32^{\prime} \mathrm{E}$. It is a volcanic island 2.1 million years old, with the first reef colonization as a reef bank, dating back to $8500 \mathrm{BC}$, when the sea level was $20 \mathrm{~m}$ lower than it is today (1). The highest point is the Piton des Neiges $3069 \mathrm{~m}$ a. s. 1. while the active volcano, the Piton de la Fournaise, is $2631 \mathrm{~m}$ high. The surface area of the island is about $2512 \mathrm{~km}^{2}$ and the diameter $70 \mathrm{~km}$.

The rainfall regime of the island is controlled primarily by the southeast trade winds. During the cool season (from June to October), the winds produce ocean swells of 1-2 m while during the hot season (from November to May) weak winds generate swells of $0.5 \mathrm{~m}$. Occasional hurricanes and storms generate very rough conditions. The tidal range varies from $0.9 \mathrm{~m}$ (springs) to $0.1 \mathrm{~m}$ (neaps).

The first human settlers arrived around 1650 , but with today's population of over 700 000 inhabitants, the island is considered overpopulated. Due to the steep topography, the population is concentrated close to the coast $(82 \%)$.

There are 3 main categories of coastal environment in Reunion namely: coral reefs with sandy beaches, volcanic rubbles, and steep cliffs. The common reef geomorphology includes an outer slope, outer and inner reef flats and a back reef. The fringing reefs are discontinuous and narrow (less than $550 \mathrm{~m}$ wide) and they only cover $7.3 \mathrm{~km}^{2}$. The reef flats are exposed at low water.

Large volcanic rubble is mostly found on the north and northeastern coasts; with increasing depth this is followed by volcanic sands. Volcanic cliffs are found on the south and southeast, due to the recent volcanic activity. Natural harbors and coves are rare.

Since the volcano is young and the continental shelf is narrow, the depth increases very rapidly near the shore. The Exclusive Economic Zone (EEZ) surrounding Reunion Island is about $320000 \mathrm{~km}^{2}$. With the exception of a few seamounts the ocean is very deep and possibilities for bottom fishing are few. Being situated at the southern limit of the South Equatorial Current, sea surface temperature varies between $22^{\circ}$ and $28^{\circ} \mathrm{C}$. At the depth of $200 \mathrm{~m}$ the temperature is around $20^{\circ} \mathrm{C}$ throughout the year.

Environmental conditions are not favorable for the concentration of large tuna schools, however tunas are abundant in the area and are the target of the longline fishery. The management of the EEZ and its resources is governed by the European Union.

\section{RESEARCH IN REEF ECOLOGY}

Reunion reefs have been studied by the Marine Ecology Laboratory since the 1970s. During this period when the reef were considered to be healthy, the first studies were of a more taxonomic and descriptive nature (1). However, in recent years the focus of research activities has changed to examine: i) function, degradation and restoration of reefs; and ii) reef biodiversity and resource management.

\section{Coral Function, Degradation, and}

Restoration

The reef communities constitute dynamic assemblages, with thousands of species interacting biologically, and with the physicochemical environment. Thus, the function of a "normal" reef, if it still exists, was examined at different levels: ecosystem, community, and species. At the ecosystem level, reefs are shallow and their metabolism is intense. The overall metabolism was studied by the flux method that quantifies the primary production and calcification $(2,3)$. Particular attention was given to nutrients, derived from terrestrial inputs as well as from community metabolism. At the community level, diversity, trophic structure, and percentage cover of the main constituents were quantified and monitored over time at a few referenced stations $(4,5)$. Species level functions were examined through studies of the dynamics and biological activity of populations of key species. Corals, fishes and echinoderms are the major taxonomic groups, with keys species on La Reunion reefs. Mechanisms such as growth, bioerosion by fish and echinoids (6), and recruitment (7) can contribute to understanding reef function.

From 1985, coral reef degradation has been observed through studies aimed at monitoring physicochemical and benthic

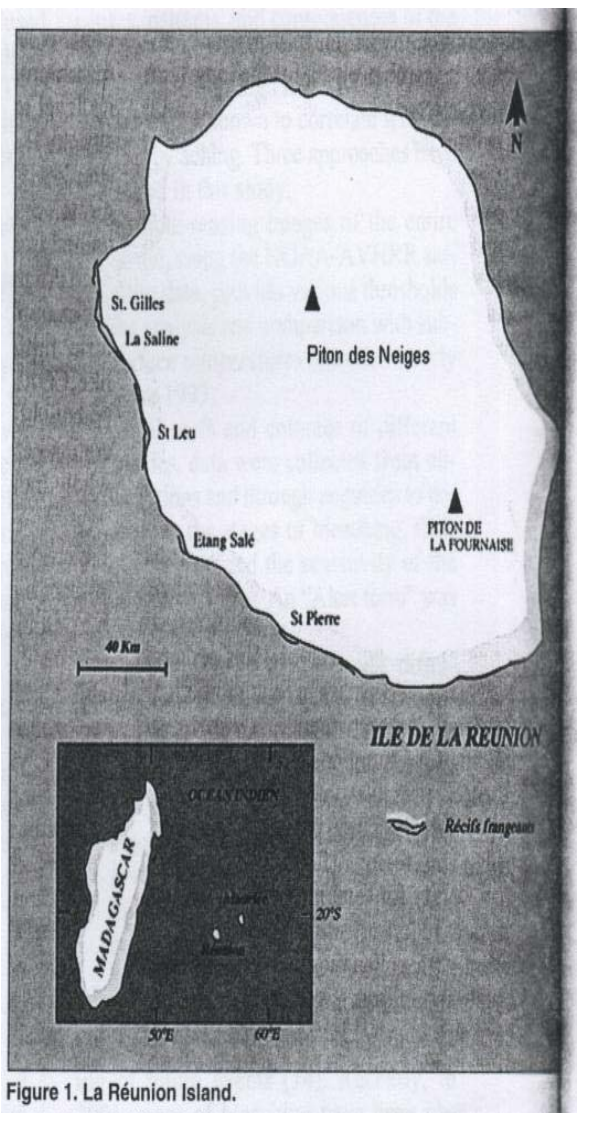

parameters to determine the level of pollution in reef flats. As benthic community structure is well-known and is permanently monitored, changes to the benthic communities are more easily detected and could be interpreted in terms of their responses to natural and/or anthropogenic stresses $(5,8)$. The principal factors of perturbation on the reef flats were analyzed and it was found that natural events, such as hurricanes, have been responsible for up to $100 \%$ coral mortality (9). Other factors that have impacts on reefs included excess nutrients through groundwater seepage, sedimentation (from soil erosion inland) lowered salinity due to surface water flow, and industrial wastes. Some communities on the outer slopes are also degraded by sedimentation in areas close to rivers, but also due to fishing, anchoring, and by ground water seepage. The ecological response of a reef to different impacts can be shown at different levels. At the ecosystem level, the degree of alteration of the benthic communities was determined by analyzing the health and the percentage of mortality of corals, as well as the relative 
abundance of potential competitors like sites, with different degradation levels the at TC).

cyanophytes, algae, and sponges (5). Other populations are very different and bioerosion is factors that accentuate the stress on corals much lower (11). In addition, the replacement remain to be quantified. These include: human of coral-dominated by algae-dominated reef activities such as reef walking and fishing; communities has been recorded in several reef coastal constructions which modify sand sites on the SaintGilles La Saline reef over the dynamics and contribute to silting-up of last 20 years. Most of our studies have focused lagoons; and coral bleaching which occurs on 3 areas of the reef flat, Planch'Alizes (PL) sometimes in summer when coinciding with Trois-Chameaux (TC), and Trou d'Eau (TE). very low tides during the day.

Their benthic communities, algal biomass,

The comparison of specific metabolic abundance of herbivorous fish, bioerosion by parameters such as net production and cal- Echinometra, and gross primary production to cification-the difference between dissolution respiration ratio, reflect the oligotrophic state of and precipitation-reveal large differences TC and TE and the dystrophic state of PL. This between normal and degraded reefs. For condition was early attributed to a combination example, lower calcification rates and $\mathrm{Pb} / \mathrm{R}$ of natural and anthropogenic

ratio values $<1$ were recorded in degraded factors such as accidental events (e.g. very low areas (3). Bioerosion, determined as an index, is tides), nutrient-enriched groundwater discharges also useful in evaluating carbonate budgets for into the back reef, and lack of sea urchins. reefs. Echinoids can be major bioeroders of Furthermore, patterns of inorganic nutrient flux coral reefs when their populations are dense and food processing by the fish Stegastes and and/or composed of large individuals. Sea sea urchin

urchins Echinometra mathaei, very abundant on Tripneustes, 2 dominant herbivores on these the fringing reefs in La Reunion, have been reefs, suggest that recycling might increase sampled to determine their contribution to the nutrient availability at PL $(12,13)$. Some carbonate budgets of the reef flats and the back worrying features of PL compared to TC and reef. They are very effective bioeroders on the TE are a low fish species richness (43 vs 65 at outer reef flat $\left(23 \mathrm{~g} \mathrm{CaCO}_{3} \mathrm{~m}^{-2} \mathrm{day}^{-1}\right)$ in the con- $\left.\mathrm{TC}\right)$, a decreasing number of juvenile fish, and trol nondegraded zone $(6,10)$. On other

a low net calcification $\left(1.5 \mathrm{~kg} \mathrm{CaCO}_{3} \mathrm{~m}^{-2} \mathrm{day}^{-1} \mathrm{vs}\right.$ 5.8

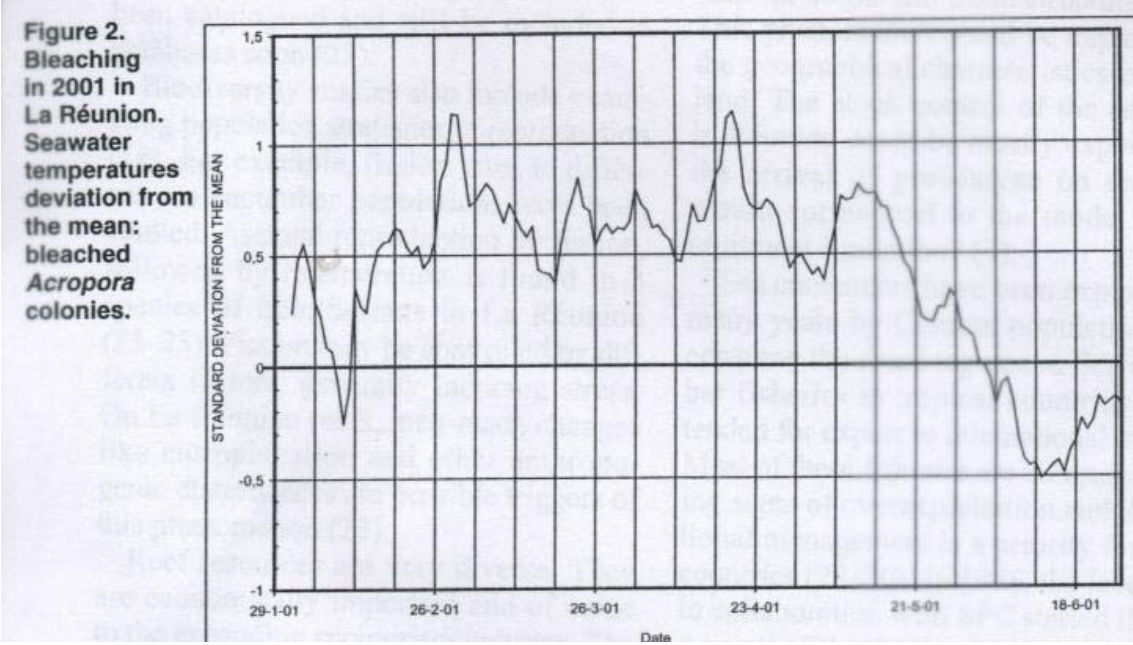

The coral bleaching event of 1997/1998 prompted the development of a multidisciplinary team, in 1998 from the Reunion university in collaboration with the French Ministry of Overseas to conduct studies to better understand the causes, patterns, and consequences of the bleaching event in $\mathrm{La}$ Reunion. Temperature maxima and high mean monthly values have been shown to correlate with the onset of bleaching. Three approaches have been used in this study:

i) Remote-sensing images of the entire island, using the NOAA-A VHRR satellite data, provide various thresholds for analysis and comparison with subsurface temperatures recorded hourly since 1993 .

ii) Local reefs and colonies of different species, data were collected from observations and through enquiries to determine the stages of bleaching, their progression and the sensitivity of the different species. An "Alert form" was used for the purpose.

iii) Following the death of corals, different stages of colonization by filamentous algae have been identified and characterized, in order to identify the epiphytic succession of the microalgal assemblage. Their prevalence is favorable to the growth of toxic

dinoflagellates and an increase of ciguatera may occur as a possible consequence of bleaching.

These complementary approaches have provided the tool, for a better understanding of future events (14). Recently, in 2001, signs of bleaching have been observed which corresponded to a long period of warmer than average water temperature (15) (Fig. 2).

Restoration is a more applied theme. The analysis of the imbalance of degraded reefs in different types of environments (from the physicochemical point of view, as well as from biotic interactions) helps to form an understanding the natural coral restoration. Concerning reef restoration, first experiments, by coral cuttings or

Bleached Acropora colonies. Photos: M. Rard.
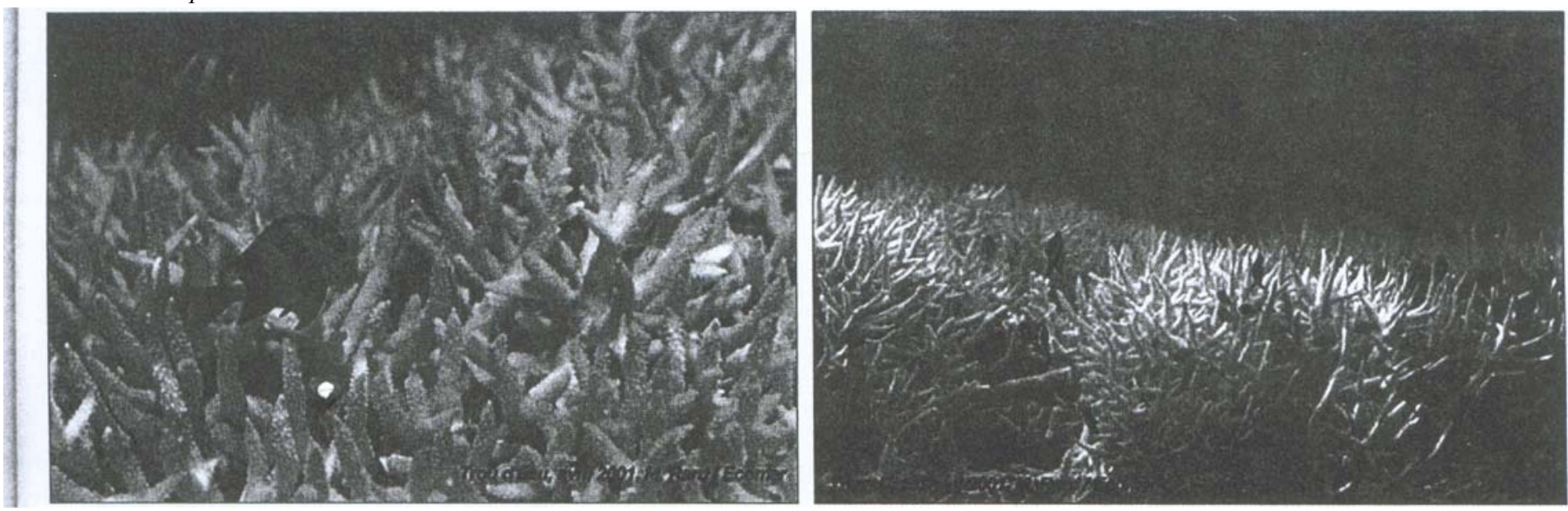
nubbins, sponsored by the Regional Council have given promising results. Coral transplantation, with their associated fish on artificial DCF (Fauna Aggregating Device), has been sponsored by the French Ministry of Environment and the multidisciplinary program (PPF) of the university $(16,17)$.

\section{Reef Biodiversity and Resources Management}

Biodiversity is currently being studied by several zoological groups using different approaches. Hydrozoans from different habitats have been collected as part of a long-term study. More than 90 species have already been identified $(18,19)$. Corals have been extensively studied (20), and the university laboratory hosts a referenced collection for the Mascarenes. These data and information have been put into databases, which can be accessed by different experts for their research work and taxonomic needs. A collaborative program has been initiated to bring together French scientists from different institutions to access data and information on coral in their archives (21). The aim is to promote utilization of computer-aided systematic tools for describing, classifying, and identifying coral specimens. Coral, reef fish and echinoderms species have been catalogued and will be included in databases soon (22).

Biodiversity studies also include examining population strategies in reproduction (18). For example, fission rates in different sea cucumber populations have been studied. Asexual reproduction by fission, followed by regeneration is found in 3 species of holothurians in La Reunion (23-25). Fission may be controlled by different factors, generally inducing stress. On La Reunion reefs, man-made changes like eutrophication and other anthropogenic disturbances are possible triggers of this phenomenon (23).

Reef resources are very diverse. They are economically important and of value to the expanding ecotourism industry. The Marine Ecology Laboratory (ECOMAR) is involved in the Indian Ocean Commission Environment Program and has produced a manual for use in monitoring the reefs of the region $(26,27)$. Fish and holothurians are among the fishery resources that have been studied extensively. The colonization of fringing reefs by fish larvae has also been studied. Essentially, it takes place from August to February with 2 peaks, in August-September when the water temperatures are the lowest and to February when the water temperature is at a maximum. The number of individual fish, as well as the number of sampled species, presented similar values over 2 consecutive years with, nevertheless, a strong variation in

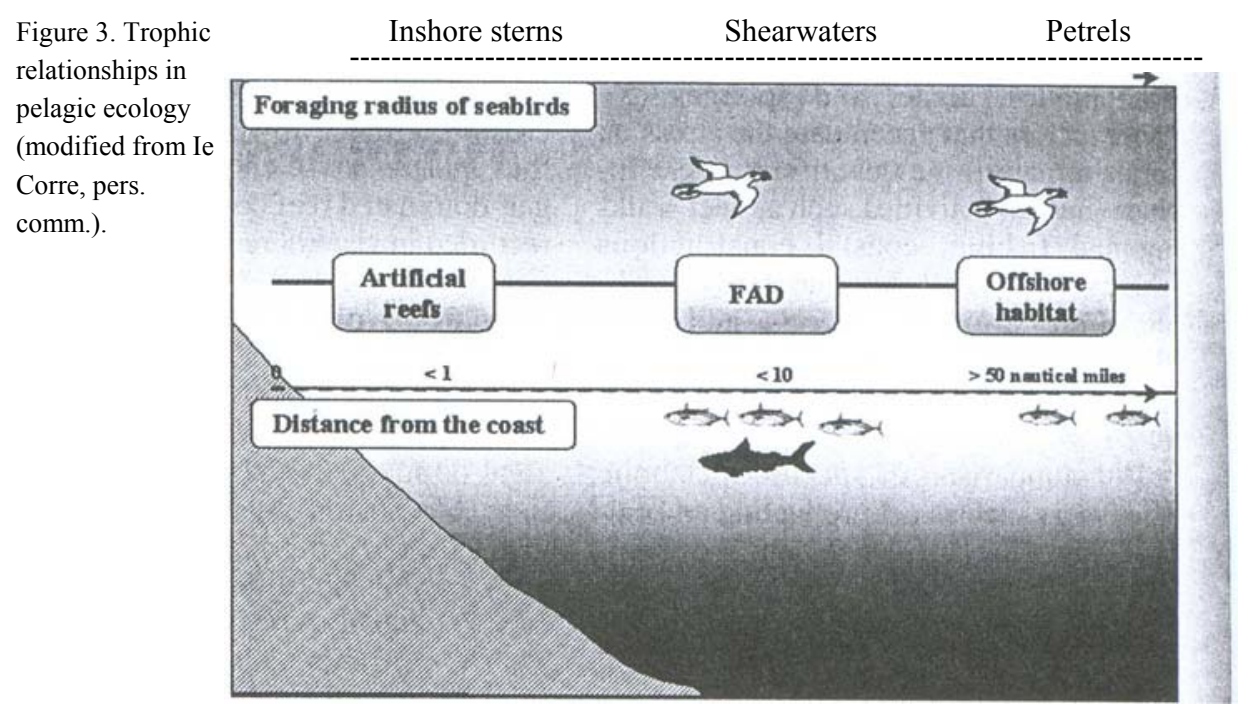

DCF: Fauna Aggregating Device

SPC: Secretariat of the Pacific Community

IFREMER: French Institute for Exploitation of the Sea

IRD: Research Institute for development

CPER: Contrat de Plan Etat-Region

CRPMEM: Regional Committee for Marine Fisheries

FAD: Fish Aggregating Device

ARDA: Regional Association for Aquaculture Development ICRI: International Coral

Reef Initiative

CORDia: Coral Reef Monitoring Network

PPF: Programme Pluriformations Mer

WIOMSA: Western Indian Ocean Marine Science Association

the species involved. The number of postlarvae which colonize the reef is lower than on larger and more structured reefs. This phenomenon could be explained by the geographical characteristics of the island. The stock control of the adult fish in Reunion could be mostly explained by the arrival of post-larvae on reefs and would correspond to the model of "recruitment limitation" (7).

Sea cucumbers have been exploited for many years by Chinese populations who consume the dried tegument. Sea cucumber fisheries in tropical countries are intended for export to international markets. Most of these fisheries are currently showing signs of overexploitation and their rational management is a priority for many countries (28-30). In 1988 , the laboratory in collaboration with SPC started the production of the Beche-de-mer Information Bulletin which is now widely distributed worldwide to raise awareness on sea cucumbers. Facing the current overexploitation problems, research initiatives to farm sea cucumber are encouraged.

\section{MAIN PROGRAM IN MARINE ECOLOGY}

There are several ongoing research programs undertaken by different organizations. ECOMAR in collaboration with IFREMER and the Research Institute for Development (IRD) is implementing a project on the dynamics of coastal and high seas of tropical ecosystems, which includes 2 main research areas: i) impact of artificial reefs on communities; and ii) trophic relationships in tropical high seas environment. This collaboration will run for 6 years through an agreement between the French State and the Reunion Region (CPER).

Given the overexploitation of the reef resources, artificial reefs have been developed by professional fishermen (CRP- I MEM) since 1995. They are set up in large bays where the fish fauna are limited. Their aggregating effects have been analyzed by visual and video observations of fish and other fauna. Functional relationships between the benthic and pelagic communities-are being monitored.

The study of the trophic relationships in a tropical high seas environment has recently been initiated $(31,32)$. The Figure 3 shows the interactions between seabirds $J$ and fish near the coast (less than 10 miles) and offshore.

The IRD formerly ORSTOM, is active in large-scale oceanographic and the satellite observations and interpretation. In 2000, IRD implemented the THETIS program, which amongst others focused on the predator-prey interactions in some high seas pelagic ecosystems of the Atlantic and Indian Oceans (33). These interactions are based on stomach-content analyses, carbon and nitrogen stable isotope ratios and acoustic surveys. The implementation of these research activities will lead to a better knowledge of the trophic ecology of apex predators and will provide an ecosystem point of view that is necessary in high-seas fisheries management. The predator-prey interactions cannot be studied over the whole oceanic 
basin, therefore, some representative areas will be selected for sampling. In the Indian Ocean, studies are conducted in 4 areas; Somalia, Seychelles-Chagos, Mozambique Channel, and Mascarenes. The results may allow for development of a trophodynamic model and analysis of the functionalities of the studied ecosystems.

Other research focuses on the relationships between environmental variability, the exploitation and the spatial dynamics of tuna populations (in cooperation with IRDIREMIA/UR). The ACTIVE program also conducted by IRD, focuses on research concerning the behavioral ecology of pelagic fish. It studies the behavioral mechanisms which lead fish to school or to form aggregations around fish aggregating devices (FADs). Furthermore, acoustic and video observations are planned under the artificial reefs built in shallow water near the reef coast. As they aggregate small pelagic fish and oceanic larvae, these small attractive structures are of interest for both programs (IRDECOMAR).

The IFREMER station is involved in several research programs. The study of long-line fishing is currently implemented jointly between ECOMAR and IRD and consists of 6 components:

i) Fisheries statistics of Reunion fishery

using the information in the database;

ii) Xiphias gladius (swordfish) reproductive

biology and growth.

iii) Behavior of the main fish in response

to the use of hooks.

iv) Relations between the fishery resource and the oceanographical conditions

studied by the IRD Seas station.

v) Fishery management strategies.

vi) Growth of Thunnus obesus $(34,35)$.

A local center, CEDTM in collaboration with ARDA, is currently developing an intensive marine fish culture in land-based facilities and in floating cages. Fish Aggregating Devices (FAD) are important for $\mathrm{La}$ Reunion fisheries and have been studied (36, 37). In 2000, IFREMER with the help of CPER initiated a program on the high-sea resources, focusing mainly on Coryphaena hippurus, which aggregate around epipelagic devices. Migration patterns of marine turtles (Chelonia mydas) is another aspect that has been studied for a long time.

\section{CONCLUSION}

The research on coastal and marine environment of La Reunion over the years has been conducted by different university laboratories, institutions, associations and administrations. The multidisciplinary program of the university PPF (Littoral Pole, biodiversity, and marine resources) has provided an opportunity for collaboration and development of joint research activities (38). Research on high seas through the Contrat de Plan Etat-Region (CPER), has also provided another opportunity for collaborations between ECOMAR, IRD and IFREMER teams.

Regional and international programs on coral reefs (ICRI, CORDIO, and GCRMN) have also been implemented in La Reunion, leading to generation of use

\section{References and Notes}

Montaggioni, L and Faure, G. 1980. Les n,cifs coral liens des Mascareignes (0. Indien). Coll. Trav. Centre Univ. Universite Franraise de l'Ocean Indien. 1-151.

2. Mioche, D. and Cuet, P. 1999. Metabolisme du carbone et des sels nutritifs en saison chaude sur un recif frangeant d'He haute (lie de la Reunion, Ocean Indien). CR. Acad. Sci. Paris 329, 53-59.

3. Mioche, D. and Cuet, P. Community metabolism on the reef flats at reunion (Indian Ocean): natural versus anthropogenic disturbance. Proc. 9th International Coral Reef Symposium, Bali, Indonesia, 2000. (In press).

. Chabanet, P., Ralambondrainy, H., Amanieu, M., Faure, G. and Galzin, R. 1997. Exploring relationship between coral reef substrata and fish. Coral Reefs 16.93-/02.

5. Naim, 0., Cuet, P., Mangar, V. 2000. Coral reefs of the Mascarene archipelago. In: Coral Reefs of the Indian Ocean: Their Ecology and Conservation, McClanahan, T.R., Sheppard, C. and Obura, D.O. (eds), Oxford University Press. pp. 353-381.

6. Conand, C, Chabanet, P., Cuet, P. and Letourneur, Y. 1997. The carbonate budget of a fringing reef in La Reunion. Int. Congr. ReefS, Panama, I, 953-958.

7. Durville, P., Bose, P., Galzin, R. and Conand, C 2002.

Colonisation des poissons coralliens sur un recif frangeant de lile

de la Reunion: richesse specifique, abondance et variations temporelles. Oceano/. Acta. 25,23-30.

8. Frouin, P. 2000. Anthropogenic disturbances of tropical softbottom benthic communities. Mar. Eeal. Progr. Ser. 194,39-53.

9. Naim, 0., Chabanet, P., Done, T., Tourrand, C. and Letourneur, Y. Regeneration of a reef flat ten years after the impact of the cyclone Firinga (Reunion, SW Indian Ocean). Proc. 91h International Coral Reef Symposium, Bali, Indonesia, 2000. (In press).

10. Conand, C., Heeb, M., Peyrot-Clausade, M. and Fontaine, M.F. 1998. Evaluations of bioerosion by two types of the sea urchin Echinometra mathaei, on several sites of a fringing reef in La Reunion Island (Indian Ocean) and comparison with other sites. In: Echinoderms: San Francisco. Mooi, R. and Telford, M. (eds). Balkema, A.A. Rotterdam, pp. 609-615.

11. Peyrot-Clausade, M., Chabanet, P., Conand, C., Fontaine, M.F, Letourneur, Y. and Harmelin-Vivien, M. 2000. Sea-urchin and fish bioerosion on La Reunion and Moorea reefs. Bull. Mar. Sci 66, 477-485.

12. Lison de Loma, T., Conand, C., Harmelin-Vivien, M.L and Ballesteros, E. Food selectivity of Tripneusles gratilla (L) (Echinodermata: Echinoidea) in oligo trophic and nutrient-enriched coral reefs at La Reunion (Indian Ocean). Bull. Mar. Sci. (In press).

13. Lison de Loma, T., Conand, C. and Harmelin-Vivien, M.L Trophic fluxes, eutrophication and the herbivore pathway: case study of a fish and a sea urchin reef resident at La Reunion (Indian Ocean). Proc. 9" International Coral Reef Symposium, Bali, Indonesia, 2000. (In press)

14. Conand, C., Larue, M., Quod, J.P., Conand, F. and Turquet, J. Bleaching in a Western Indian Ocean Island, La Reunion: A multiscale approach. Proc. $9^{\text {th }}$ Int. Coral Reef Symp. Bali, Indonesia, 2000. (In press)

15. Turquet, J., Mirault, E., Conand, C., Conand, F., Rard, M., Cambert, H. and Quod, J.P. 2001. Reponse au phenomene de blanchissement corallien observe a La Reunion en mars-avril 2001. Rapporl APMR, $35 \mathrm{pp}$

16. Chabanet, P. and Naim, O. 2000. Restauration d'un platier recifal corallien par Ie biais de transplantation de coraux scleractiniaires branch us, isoles et/ou associes a leur faune ichtyologique, et de la pose de structures artificielles. Rapporl Ministere Environnemenl/ ECOMAR. Programme National "Recreer la nature: rehabilitation, restauration et creation d'ecosystemes", $100 \mathrm{pp}$.

17. Esbelin, C, Chabanet, P., Naim, 0., Ratsifandrihamanana, F.. and Tourrand,. C. 2001. Restauration d'un platier recifal corallien a la Reunion. Colloque "Recreer la .nature: rehabilitation, restauration et creation d'ecosystemes" (poster)

18. Gravier-Bonnet, N. and Migotto, A. 2000. Gonangium development and medusoid of Nemalecium lighli (Hargitt, 1924) (Cnidaria: Hydrozoa, Haleciidae). Scientia Marina, 64, 207-213.

19. Gravier-Bonnet, N. and Lebon, M.-L Life cycle with free medusoids (swimming gonophores) for two Serlularella species from Reunion island (Cnidaria, Hydrozoa, Sertulariidae-Indian Ocean). Inverl. Reprod. Develop. (In press).

20. Faure, G. 1982. Recherche sur les Peuplements des Scleractiniaires des Recifs Coralliens de l,Archipel des Mascareignes (Ocean Indien Occidental). These de ful data on different research aspects. With regard to the collaboration with other institutions in the Western Indian Ocean region, opportunities .now exist particularly through different activities implemented by WIOMSA such as the Marine Science for Management (MASMA) Programme.

Doct.es Sciences, Univ. Aix-Marseille, France, 2, I: 206 pp.

1. Conruyt, N., Grosser, D., Geynet, Y., Faure, G., Pichon, M. Guillaume, M. and N. Gravier-Bonnet. IKBS, a Knowledge Base Management System for reengineering Systematic: application to corals of the Mascarene Archipelago. Proc.. $9^{\text {th }}$ Int. Coral Ree Symp. Bali, Indonesia, 2000. (In press).

22. Conand, C. and Gravier-Bonnet, N. 2001. Biodiversite du milieu recifal reunionnais: les echichodermes et les hydra ires. Rapport Convention Conseil Regional 1998, 60 pages (rapport: I-II annexes: 12-60).

23. Conand, C, Uthicke, S. and Hoareau, T. Sexual and asexual reproduction of the holothurian Slichopus chloronolu. (Echinodermata): a comparison between La Reunion (Indian Ocean) and east Australia (Pacific Ocean). Inverl. Reprod. Develop. (In press).

24. Uthicke, S., Conand, C and Benzie, J.A.H. 2001. Population genetics of the fissiparous holothurians Slie/lOpl/s chloronotl/s and Holothuria atra (Aspidochirotida): a comparison between Torres Strait and La Reunion. Mar. Bioi. 139, 257-265.

25. Hoareau, T. and Conand, C 2001. Sexual reproduction of Slichopus chloronolus, a fissiparous sea cucumber, on Reunion Island, Indian Ocean. SP.C Beche-de-mer Inform. Bull. 15.4-12.

26. Conand, C., Chabanet, P., Bigot, L and Quod, J.P. 2000 Guidelines for Coral Reef Monitoring in the South-West Region of the Indian Ocean. PRE/COI $27 \mathrm{pp}$

27. Chabanet, P., Bigot, L, Naim, 0, Garnier, R., Tessier, E. and Moyne-Picard, M. Coral reef monitoring at Reunion island (Western Indian Ocean) using the GCRMN method. Proc. $9^{\text {th }}$ International Coral Reef Symposium, Bali, Indonesia. (In press).

28. Conand, C. 1999. Manuel de Qualite des Holothuries Commerciales du Sud-Ouest de l,Ocean Indien. Commission Ocean Indien 39 pp.

29. Conand, C. 2001. Overview of sea cucumbers fisheries over the last decade-what possibilities for a durable management? In: Echinoderm 201JO, Barker (ed.), Swets \& Zeitlinger pp. 339344

30. Hamel,J.-F., Conand, C., Pawson, D.L and Mercier, A. 2001 Biology of the sea cucumber Holothuria scabra (Holothuroidea: Echinodermata) and its exploitation as beche-de-mer. $A d v . M a r$ Bioi. 41, 129-223.

3 I. Jaguemet, S. 2001. Apport des Predateurs Apicala dans l'Ett/de du Role Trophique des Dispositifs de Concentrations de Poissons (DCP) dans /'Ecosysteme Oceanique des Abords de La Rellnion. Memoire de DEA "Oceanologie Biologique et Environnement Marin Option Parametrisation et Modelisation". Universite Paris VI - Universite de La Reunion (ECOMAR).

32. Le Corre, M. 2001. Breeding seasons of seabirds of Europa Island in relation with seasonal changes of the marine environment. $\mathrm{J}$. Zoo/. (London) 254, 239-249.

33. Potier, M., Sabatie, R., Menard, F. and Marsac, F. 2001 Preliminary results of tuna diet studies in the West Equatorial Indian Ocean. CTOI session, June 2001

34. Conand, F. and Stequert, B. 2000. Programme Palangre Rhmion; Operation 6: Croissance du Patudo. Rapport d'avancement 2000: $37 \mathrm{pp}$

35. Stequert, 13. and Conand, F. 2000. Preliminary studies of age and growth of Bigeye tuna (Thunnus obesus) in the western Indian. Second meeting of the working party on tropical tunas; 10TC, Mahe, Seychelles, Septembre 2000

36. Le Gall, J.Y., Cayre, P. and Taquet, M. (eds) 2000. Peche thoniere et dispositifs de concentration de poissons. Ed. Ifremer, Actes Colloques, $684 \mathrm{pp}$.

37. Le Gall, J.Y., Cayre, P., Taquet, M. (eds) 2000. Mechanisms and effects of the aggregation of tuna by FADs. Aqua. Liv. Res. 181 264.

38. Conand, C. and Frouin, P. 2002. Programme plurifolmations pole mer littoral, biodiversite et ressources marines. Actes du seminaire 16 mai 2001. J. Nailire 14, 1- 76 pp.

39. Acknowledgement: This synopsis has benefited from the inputs from ECOMAR, IRD, and IFREMER scientists.

\section{Chantal Conand}

Laboratoire ECOMAR

Universite de La Reunion

97715 Saint-Denis meso cx 9 France Email: Chantal.Conand@helios.univreunion.fr 